\title{
Elaboration of immunoenzymatic test-kit for total human IgE assay and investigation of its analytical properties
}

\author{
Galkin A. Yu., Dugan A. M. \\ Department of Industrial Biotechnology, National Technical University of Ukraine "Kyiv Polytechnic Institute”, Kyiv, Ukraine
}

\section{Email address:}

alexander.yu.galkin@gmail.com (A. Yu. Galkin)

\section{To cite this article:}

Galkin A. Yu. , Dugan A. M. . Elaboration of Immunoenzymatic Test-Kit for Total Human IgE Assay and Investigation of Its Analytical Properties, International Journal of Immunology. Vol. 1, No. 1, 2013, pp. 1-6. doi: 10.11648/j.iji.20130101.11

\begin{abstract}
Enzyme-linked immunosorbent assay (ELISA) test-kit has been developed based on complex immunochemical, including epitop mapping, characteristics of monoclonal antibodies (MAbs) to human IgE. "Sandwich" type ELISA based on usage of different epitop directionality MAbs. It has been founded correlation between affinity of different MAb pairs and its sorbtion-detection ability. Optimal configuration of MAbs in "sandwich" ELISA was following: 164H10 - 165C12 and 164H10 - 166B7. Cooperative usage of horseradish peroxidase conjugates of MAbs directed to different epitops (165C12-HRP + 166B7-HRP) increased analytical sensitivity of assay and constituted $4.5 \mathrm{IU} / \mathrm{ml}$. Analytical characteristics of developed test-kit were following: dynamic range - from 4.5 to $1600 \mathrm{IU} / \mathrm{ml}$, variation coefficient value during one procedure $-4.2 \pm 2.1 \%$, and between procedures $-4.8 \pm 2.3 \%$. Presences of human $\operatorname{IgG}, \operatorname{IgA}$, $\operatorname{IgM}$, albumin $(1 \mu \mathrm{g} / \mathrm{ml})$ were not effect on the assay specificity (test concentration of $\mathrm{IgE}-50 \mathrm{IU} / \mathrm{ml}$ ).
\end{abstract}

Keywords: Human IgE, Monoclonal Antibodies, Immunoenzymatic Analysis

\section{Introduction}

In 1921 experiments of two German doctors C. Prausnitz and $\mathrm{H}$. Kustner have shown that allergy sings are associated with serum factor, specified by A. F. Coca as "reagines" in 1925 [1]. Only in 1966-67 K. Ishizaka, T. Ishizaka, M. Hornbrook [2] in the United States and H. Bennich and C. Johansson [3] in Sweden identified the new class of immunoglobulins, named as immunoglobulin E (IgE) by experts of World Health Organization (WHO) in 1968 [4 - 5]. IgE is an antibody class present only in mammals and is a monomer glycoprotein with molecular weight $190 \mathrm{kDa}$. Fc fragment of IgE has double molecular weight compared to Fc fragment of $\mathrm{IgG}$ (100 kDa), caused by additional 100 amino acid residues (it contains the additional forth $\mathrm{CH}$-domen). $\mathrm{IgE}$ is mainly synthesized in skin lymphoid tissue, respiratory tracks, bowel and lymph nodes, that provide their drainage [1]. The main function of IgE is prevention of the body from helminths and protozoons [ $6-7]$. IgE is also very important in I type hypersensitivity shown by various allergic disorders, such as allergic asthma, allergic rhinitis, food allergy, atopic dermatitis, anaphylactic reaction etc.

Immunoglobulins concentration of other types namely
IgG and IgM (normal serum concentration 1-10 mg/ml) are mostly identified by nephelometry or turbidimetry $[8,9]$. But these methods are not sensitive enough to identify IgE. It is well-known that average normal serum concentration of IgE amounts to $50 \mathrm{ng} / \mathrm{ml}(2.4 \mathrm{ng} / \mathrm{ml}$ corresponds to $1 \mathrm{IU} / \mathrm{ml}$ ). Obviously, such a low level of target immunoglobulin does not allow usage of the serum as source material for IgE separation. A number of diseases can considerably cause increase of serum IgE [10 - 12], for example: allergic rhinitis - up to $1000 \mathrm{IU} / \mathrm{ml}$, atopic bronchial asthma - up to $1200 \mathrm{IU} / \mathrm{ml}$, helminthosis and parasitic invasion - up to $2000 \mathrm{IU} / \mathrm{мл,} \mathrm{allergic} \mathrm{broncho-}$ pulmonary aspergillosis (acute phase) - up to $8000 \mathrm{IU} / \mathrm{ml}$, atopic and diffuse dermatitis - up to $14000 \mathrm{IU} / \mathrm{ml}$. Usage of serum IgE with concentration not less than $2000 \mathrm{IU} / \mathrm{ml}$ as a source material is considered to be reasonable.

Enzyme-linked immunosorbent assay (ELISA) is known for its high sensitivity needed for such diagnostics purposes. Our goal was to elaborate the high sensitivity analysis for human IgE assay. This task could be solved by means of supersensitive biological reagents like monoclonal antibodies (MAbs).

The study goal consists of: development of the ELISA test-kit for total human IgE assay based on complex spe- 
cification of monoclonal antibodies to human $\operatorname{IgE}$ and investigation of its analytical properties.

\section{Materials and Methods}

Indirect ELISA technique. Sorption of $\operatorname{IgE}$ and Fcfragments of $\mathrm{IgE}$ was performed in $0.05 \mathrm{M}$ carbonate/bicarbonate buffer $(\mathrm{pH} 9.6)$ over the night at $4{ }^{\circ} \mathrm{C}$ with concentration of 5 and $2.5 \mu \mathrm{g} / \mathrm{ml}$ correspondingly. For washing procedure a phosphate-buffered saline (PBS) added with $0.05 \%$ twin-20 (PBST), $\mathrm{pH} 7.2$ - 7.4, was used. The plate was incubated for 1 hour at $37^{\circ} \mathrm{C}$ followed by washing. For bound antibodies detection there was used the goat antibodies conjugate to mouse immunoglobulin with horseradish peroxidase (HRP), incubated for 1 hour at room temperature. The plate was washed for three times with PBST and once with water. $0.003 \%$ peroxide solution in $0.15 \mathrm{M}$ citrate buffer ( $\mathrm{pH}$ 5.0) was used as a substrate; 3,3',5,5'-tetramethylbenzidine (TMB) was used as a chromogene. The reaction was halted by $2 \mathrm{M}$ sulfuric acid. After that the optical density (OD) at wavelength of $450 / 620 \mathrm{~nm}$ was measured.

Competitive ELISA technique. This analysis modification was used for epitope specificity of the received MAbs. Human IgE was sorbed in $0.05 \mathrm{M}$ carbonate/bicarbonate buffer at the given concentration of $5 \mu \mathrm{g} / \mathrm{ml}$ on ELISA 96cell plates. The plate was incubated during the night at $4{ }^{\circ} \mathrm{C}$ followed by duplicate PBS washing. Every plate cell was filled with the being studied MAb peroxidase conjugate. After this step and for competitive purpose cells from different rows were filled with MAbs of other clones in various concentrations: the investigators started from $0.4 \mathrm{mg} / \mathrm{ml}$ and every next time they used double dissolution. Difference of MAbs conjugate optical density and assay optical density under competition of homonymous MAbs was used as reference. The rest of the procedure was carried out as the indirect ELISA technique.

Antibodies affinity measurement. MAbs affinity constant was measured by inhibition method [13]. Different concentrations of $\operatorname{IgE}\left(10^{-9}-10^{-6} \mathrm{~mol} / \mathrm{l}\right)$ were mixed with samples of cultural fluids containing MAbs. Incubated samples (for 1 hour at $37^{\circ} \mathrm{C}$ ) were transferred to 96-cell plate previously sensibilized by human IgE. The indirect ELISA procedure was performed upon that. Samples of cultural fluids without preliminary $\operatorname{IgE}$ incubation were used as reference.

$M A b$ isotype determination. Isotype of the received monoclonal antibodies was determined by means of standard set for isotyping ISO-2 ("Sigma", USA).

Synthesis of peroxidase conjugates. Conjugating of MAbs with horseradish peroxidase was performed in mass ratio 2:1 of antibodies to enzyme using P. Tijssen periodate oxidation method [14] with own modifications. Horseradish peroxidase ("Sigma", USA) was solved in $0.1 \mathrm{M}$ bicarbonate buffer ( $\mathrm{pH} 8,3$ ) to the concentration of $15 \mathrm{mg} / \mathrm{ml}$ and added the equal volume of $14 \mathrm{mM}$ sodium periodate water solution. For oxidation purpose HRP mixture was incubated for 2 hours at room temperature. The received solution of the oxidized HRP was mixed with antibodies solution preliminary dialyzed from $0.1 \mathrm{M}$ carbonate buffer ( $\mathrm{pH}$ 9.2). The mixture was transferred to the chromatogram column and added with $1 / 3$ of dry Sephadex G-25, incubated for 3 hours at room temperature. Conjugate solution was eluted from the column and added by $1 / 20$ of $\mathrm{NaBH}_{4}$ water solution volume part $(5 \mathrm{mg} / \mathrm{ml})$. In order to halt the reaction the mixture was left for 30 minutes at room temperature, added more $3 / 20$ parts of $\mathrm{NaBH}_{4}$ solution, incubated for $60 \mathrm{~min}$. The received solution of MAbs peroxidase conjugate was under dialysis transferred into $0.02 \mathrm{M}$ phosphate buffer with $0.15 \mathrm{M}$ $\mathrm{NaCl}$.

\section{Results and Discussion}

In order to solve the task it is necessary to get the set of monoclonal antibodies to human $\operatorname{IgE}$ and to perform complex study of MAbs biological properties. Monoclonal antibodies were received on short period immunization scheme (7-8 days): antigen was injected into mice hindfoot pads in total dosage $50 \mu \mathrm{g}$ IgE per animal, first two injections were done with full Freund's adjuvant ("Sigma", USA), the third injection was done without adjuvant. Hybridization was carried out by means of lymphocytes from regional mice lymph notes. The study data have been particularly described before [15], their summarized results are presented in table 1.

The next study step was devoted to selection of MAbs pair for "sandwich" ELISA for IgE determination purpose. According to MAbs epitope mapping of epitope regions $\mathrm{A}$ and $\mathrm{B}$ the most remote epitopes are distinguished. This was the reason why we synthesized peroxidase conjugates of all received MAbs and investigated effectiveness of $\operatorname{IgE}$ determination by monoclonal antibodies of various epitopes in "sandwich" ELISA.

For determination of MAbs optimal orientation in testkit the antibodies able to recognize different epitopes, were tested as an immunosorbent as well as peroxidase conjugates (test IgE concentration - $500 \mathrm{IU} / \mathrm{ml}$ ) (table 2 and table 3 ). When using antibodies directed to epitope B in HRP-conjugate the signal in ELISA did not exceed $0.286 \pm 0.059$, provided inadvisability of MAbs of this group for the detection purpose. At the same time MAbs of this group showed rather high signals when used in immunosorbent: the best results were registered for antibody pair B-A1 (average signal in ELISA amounted to $1.630 \pm 0.139$ ) and B-A3 (average signal in ELISA $1.706 \pm 0.093)$. Investigating different MAbs pairs, directed to A1, A2 and A3 epitopes, we received mean values of signals in ELISA provided the uselessness of such combinations.

According to the study results of MAbs properties in ELISA for detection of IgE the best antibodies for sorb- 
tion (used as immunosorbent base) were antibodies of epitope B (163D12, 164H10). At the same time in immunoenzymatic conjugate the best results were achieved for MAbs epitopes A1 (165C12, 166A10, 167B4) and A3
(161A7, 164F5, 166B7). The best MAbs pairs for "sandwich"-combination of noncompetitive ELISA were $164 \mathrm{H} 10$ - 165C12 and 164H10 - 166B7. These MAbs pairs were used for further studies.

Table 1. Characteristics of monoclonal antibodies to human IgE.

\begin{tabular}{|c|c|c|c|c|c|c|c|c|c|}
\hline \multirow{2}{*}{ MAbs } & \multicolumn{5}{|c|}{ OD in ELISA } & \multirow{2}{*}{$\begin{array}{l}\text { Antibody } \\
\text { isotype }\end{array}$} & \multirow{2}{*}{$\begin{array}{l}\text { Antibody titer in } \\
\text { culture fluid }\end{array}$} & \multirow{2}{*}{$\begin{array}{l}\text { Affinity constant, } \\
10^{9} \mathrm{M}^{-1}\end{array}$} & \multirow{2}{*}{ Epitope } \\
\hline & IgE & Fce-fragments & IgG & $\operatorname{IgA}$ & IgM & & & & \\
\hline $161 \mathrm{~A} 7$ & 2.842 & 2.742 & 0.064 & 0.036 & 0.045 & $\operatorname{IgG}_{1}$ & $1: 800$ & 10.0 & A3 \\
\hline $161 \mathrm{H} 5$ & 2.872 & 2.740 & 0.057 & 0.048 & 0.070 & $\mathrm{IgG}_{1}$ & $1: 800$ & 10.0 & $\mathrm{~A} 2$ \\
\hline $163 \mathrm{C} 10$ & 3.220 & 3.166 & 0.051 & 0.083 & 0.075 & $\mathrm{IgG}_{1}$ & $1: 500$ & 8.0 & A2 \\
\hline $163 \mathrm{D} 12$ & 3.015 & 3.097 & 0.061 & 0.096 & 0.036 & $\operatorname{IgG}_{2 \mathrm{a}}$ & $1: 800$ & 10.0 & B \\
\hline $164 \mathrm{~F} 5$ & 2.925 & 2.920 & 0.079 & 0.025 & 0.040 & $\operatorname{IgG}_{1}$ & $1: 200$ & 10.0 & A3 \\
\hline $164 \mathrm{H} 3$ & 3.005 & 2.977 & 0.033 & 0.045 & 0.045 & $\operatorname{IgG}_{2 b}$ & $1: 800$ & 10.0 & $\mathrm{~A} 2$ \\
\hline $164 \mathrm{H} 10$ & 3.017 & 3.029 & 0.015 & 0.030 & 0.035 & $\operatorname{IgG}_{1}$ & $1: 1000$ & 14.0 & B \\
\hline $165 \mathrm{C} 12$ & 2.097 & 2.111 & 0.015 & 0.091 & 0.045 & $\operatorname{IgG}_{1}$ & $1: 1000$ & 10.0 & A1 \\
\hline 166A10 & 2.950 & 2.901 & 0.041 & 0.053 & 0.029 & $\operatorname{IgG}_{1}$ & $1: 500$ & 8.0 & A1 \\
\hline $166 \mathrm{~B} 7$ & 3.001 & 3.101 & 0.486 & 0.072 & 0.069 & $\operatorname{IgG}_{2 \mathrm{~b}}$ & $1: 500$ & 10.0 & A3 \\
\hline $166 \mathrm{~F} 3$ & 2.895 & 2.861 & 0.017 & 0.061 & 0.010 & $\mathrm{IgG}_{1}$ & $1: 800$ & 10.0 & $\mathrm{~A} 2$ \\
\hline 167B4 & 2.906 & 2.972 & 0.053 & 0.048 & 0.078 & $\operatorname{IgG}_{2 b}$ & $1: 1000$ & 8.0 & A1 \\
\hline
\end{tabular}

Table 2. Effectiveness of IgE determination by monoclonal antibodies of various epitopes in "sandwich" ELISA.

\begin{tabular}{|c|c|c|c|c|c|c|c|c|c|c|c|c|c|c|}
\hline \multirow{4}{*}{ Sorption } & & & \multicolumn{12}{|c|}{ Conjugate } \\
\hline & & & \multicolumn{12}{|c|}{ Epitopes and MAbs } \\
\hline & & & \multicolumn{2}{|l|}{ B } & \multicolumn{3}{|l|}{ A1 } & \multicolumn{4}{|l|}{ A2 } & \multicolumn{3}{|l|}{ A3 } \\
\hline & & & $163 \mathrm{D} 12$ & $164 \mathrm{H} 10$ & $165 \mathrm{C} 12$ & 166A10 & 167B4 & $161 \mathrm{H5}$ & $163 \mathrm{C} 10$ & $164 \mathrm{H3}$ & $166 \mathrm{F3}$ & 161A7 & $164 F 5$ & 166B7 \\
\hline \multirow{12}{*}{$\begin{array}{l}\text { Epitopes } \\
\text { and MAbs }\end{array}$} & & 163D12 & - & - & 1.723 & 1.527 & 1.521 & 1.351 & 1.405 & 1.500 & 1.410 & 1.643 & 1.711 & 1.809 \\
\hline & & $164 \mathrm{H} 10$ & - & - & 1.892 & 1.612 & 1.505 & 1.315 & 1.517 & 1.392 & 1.031 & 1.621 & 1.605 & 1.847 \\
\hline & & $165 \mathrm{C} 12$ & 0.203 & 0.205 & - & - & - & 0.783 & 0.602 & 0.712 & 0.633 & 1.025 & 0.905 & 1.191 \\
\hline & A1 & $166 \mathrm{~A} 10$ & 0.307 & 0.241 & - & - & - & 0.650 & 0.621 & 0.694 & 0.687 & 1.115 & 0.977 & 1.010 \\
\hline & & 167B4 & 0.391 & 0.353 & - & - & - & 0.627 & 0.701 & 0.745 & 0.699 & 1.041 & 1.009 & 1.004 \\
\hline & \multirow{4}{*}{ A2 } & $161 \mathrm{H} 5$ & 0.250 & 0.244 & 0.514 & 0.433 & 0.445 & - & - & - & - & 0.982 & 0.852 & 0.952 \\
\hline & & $163 \mathrm{C} 10$ & 0.241 & 0.245 & 0.547 & 0.465 & 0.525 & - & - & - & - & 0.852 & 0.954 & 0.963 \\
\hline & & $164 \mathrm{H} 3$ & 0.311 & 0.241 & 0.415 & 0.405 & 0.577 & - & - & - & - & 0.821 & 0.821 & 1.021 \\
\hline & & $166 \mathrm{~F} 3$ & 0.408 & 0.347 & 0.420 & 0.528 & 0.529 & - & - & - & - & 0.741 & 0.801 & 0.955 \\
\hline & \multirow{3}{*}{ A3 } & 161A7 & 0.309 & 0.302 & 0.592 & 0.459 & 0.458 & 0.422 & 0.522 & 0.458 & 0.482 & - & - & - \\
\hline & & 164F5 & 0.221 & 0.115 & 0.526 & 0.522 & 0.534 & 0.403 & 0.525 & 0.425 & 0.469 & - & - & - \\
\hline & & 166B7 & 0.230 & 0.119 & 0.489 & 0.581 & 0.425 & 0.415 & 0.444 & 0.529 & 0.566 & - & - & - \\
\hline
\end{tabular}


Table 3. Effectiveness of IgE determination by monoclonal antibodies of various epitopes in "sandwich" ELISA (averaged OD in ELISA for different groups of MAbs).

\begin{tabular}{lllll}
\hline \multirow{2}{*}{ MAbs of different epitopes if used in immunosorbent } & \multicolumn{4}{l}{ MAbs of different epitopes if used in conjugate } \\
\cline { 2 - 6 } & $\mathbf{B}$ & $\mathbf{A 1}$ & $\mathbf{A 2}$ & $\mathbf{A 3}$ \\
\hline B & - & $\mathbf{1 . 6 3 0 \pm 0 . 1 3 9}$ & $1.365 \pm 0.141$ & $\mathbf{1 . 7 0 6 \pm 0 . 0 9 3}$ \\
A1 & $0.283 \pm 0.072$ & - & $0.680 \pm 0.052$ & $1.031 \pm 0.077$ \\
A2 & $0.286 \pm 0.059$ & $0.484 \pm 0.057$ & - & $0.893 \pm 0.084$ \\
A3 & $0.216 \pm 0.077$ & $0.510 \pm 0.053$ & $0.472 \pm 0.051$ & - \\
\hline
\end{tabular}

Taking into account the necessity of working out the set with maximum superior sensitivity parameter we have performed comparison studies using conjugates $165 \mathrm{C} 12$ HRP and 166B7-HRP separately and mixed (50\%/50\%). Results of the experiments are shown on fig. 1. At $1200 \mathrm{IU} / \mathrm{ml} \mathrm{IgE} \mathrm{concentration} \mathrm{in} \mathrm{the} \mathrm{test} \mathrm{sample} \mathrm{there}$ was not significant difference between signal levels in ELISA of individual conjugates and their mixture. But in case of lowering the concentration of $\operatorname{IgE}$ in the sample to $300 \mathrm{IU} / \mathrm{ml}$ we noticed the significant increase of signal in ELISA for mixed conjugates 165C12-HRP + 166B7-HRP compared to individual conjugates: signal in ELISA $1.202 \pm 0.058$ compared to $0.895 \pm 0.052$ (for $165 \mathrm{C} 12$-HRP) and $0.714 \pm 0.048$ (for 166B7-HRP). Therefore for usage in the elaborating set we selected mixture of conjugates 165C12-HRP + 166B7-HRP. Such an effect can be explained by different dimensional localization of antigen determinants on IgE molecule, where MAbs $165 \mathrm{C} 12$ (epitope A1) and 166B7 (epitope A3) are directed. At high concentrations of $\mathrm{IgE}(1200 \mathrm{IU} / \mathrm{ml})$ and correspondingly epitopes, mixed conjugates (A1-A3) do not increase assay sensitivity. However significant lowering of IgE concentration $(600-300 \mathrm{IU} / \mathrm{ml})$ in the test sample quantity of antigen determinants decreases. For this reason shared usage of antibodies conjugates, able to recognize different epitopes of IgE molecule, results to significant sensitivity growing of the elaborating ELISA test-kit.

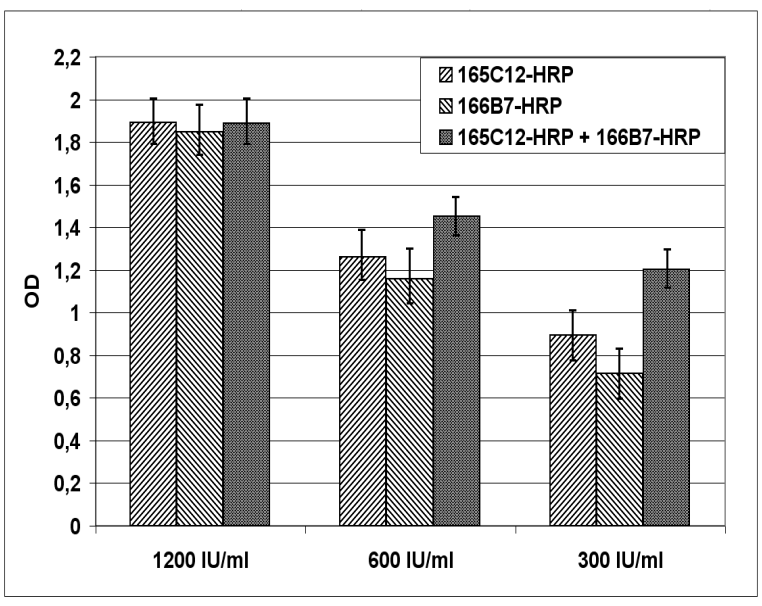

Figure 1. ELISA results at different human IgE concentrations: 165C12-HRP and 166B7-HRP conjugates used alone and mixed.
After MAbs optimal configuration in "sandwich" ELISA had been determined, the improvement of analysis performance conditions was done: determination of working concentrations for monoclonal antibodies an immunoenzymatic conjugate, analysis time and conditions, sample volume and reaction buffer content. The final protocol mentioned below is the result of the carried work and is the optimized variant of "sandwich" ELISA, analytical specifications of which were specified.

ELISA "sandwich" variant protocol. MAbs, specific to human IgE, were sorbed in $0.02 \mathrm{M}$ carbonate/bicarbonate buffer at the concentration of $2 \mu \mathrm{g} / \mathrm{ml}$ on ELISA 96-cell plates. The plate was incubated for 12 hours at $4{ }^{\circ} \mathrm{C}$, followed by triplicate PBST washing and left in bovine serum albumin solution (BSA) $(10 \mathrm{mg} / \mathrm{ml}$ in PBS) for 1 hour at $37{ }^{\circ} \mathrm{C}$. After four times of washing PBST plate cells were filled with $100 \mu \mathrm{l}$ of reaction buffer $(0.05 \mathrm{M}$ tris- $\mathrm{HCl}$ buffer, $\mathrm{pH} 8.0,0.15 \mathrm{M} \mathrm{NaCl}, 5 \mathrm{M}$ EDTA, $0.5 \mathrm{mg} / \mathrm{ml} \mathrm{BSA}, 0.2 \%$ Tween- $20,25 \mu \mathrm{g} / \mathrm{ml}$ mice MAbs, non-specific to human IgE [16]), containing $200 \mathrm{ng} / \mathrm{ml}$ $\mathrm{MAb}$ to human IgE labeled by horseradish peroxidase. Then cells were filled with $20 \mu \mathrm{l}$ of reference standardized $\mathrm{IgE}$ at the following concentrations $0,10,50,100$, 400, 800, and $1600 \mathrm{IU} / \mathrm{ml}$ (WHO, 2nd IRP, 75/502) an test samples of human serum preliminary diluted by reaction buffer 1:1000. Plates were incubated for 2 hours at $37{ }^{\circ} \mathrm{C}$ under constant stirring and washed 4 times. The further procedure was similar to indirect ELISA. Concentration of human IgE was calculated by means of calibration schedule of standard (reference) samples. If concentration of IgE in the sample exceeded $1600 \mathrm{IU} / \mathrm{ml}$, the test sample needed to be repeatedly analyzed with additional dissolution in 2-4 times.

Next study steps included determination of sensitivity limit, dynamic range, variability, specificity (cross reactivity) of the elaborated ELISA.

In order to detect the sensitivity limit first of all the mean value $(\mathrm{M} \pm m)$ of reference standard (background signal) in 20 procedures ELISA, amounting $0.021 \pm 0.003$ was determined. The sensitivity limit was calculated by calibration schedule as IgE concentration, where optical density was even $(\mathrm{M} \pm 2 \mathrm{~m}) \times \mathrm{OD}$ of the reference standard (0.042), and amounted to $4.5 \mathrm{IU} / \mathrm{ml}$.

After washing OD of reference sample from OD values of $\operatorname{IgE}$ standards there was obtained the linear stan- 
dard curve to $1600 \mathrm{IU} / \mathrm{ml}$, limited by the boundary value of OD (> 2.5) (fig. 2). Consequently the dynamic range had 3 levels $(4.5-1600 \mathrm{IU} / \mathrm{ml})$, at the same time for $t$ for the majority of commercial sets the dynamic range has 2 levels at human $\mathrm{IgE}$ determination. This dynamic range demands preliminary dilution of blood serum/plasma and other biological liquids for the analysis performance.

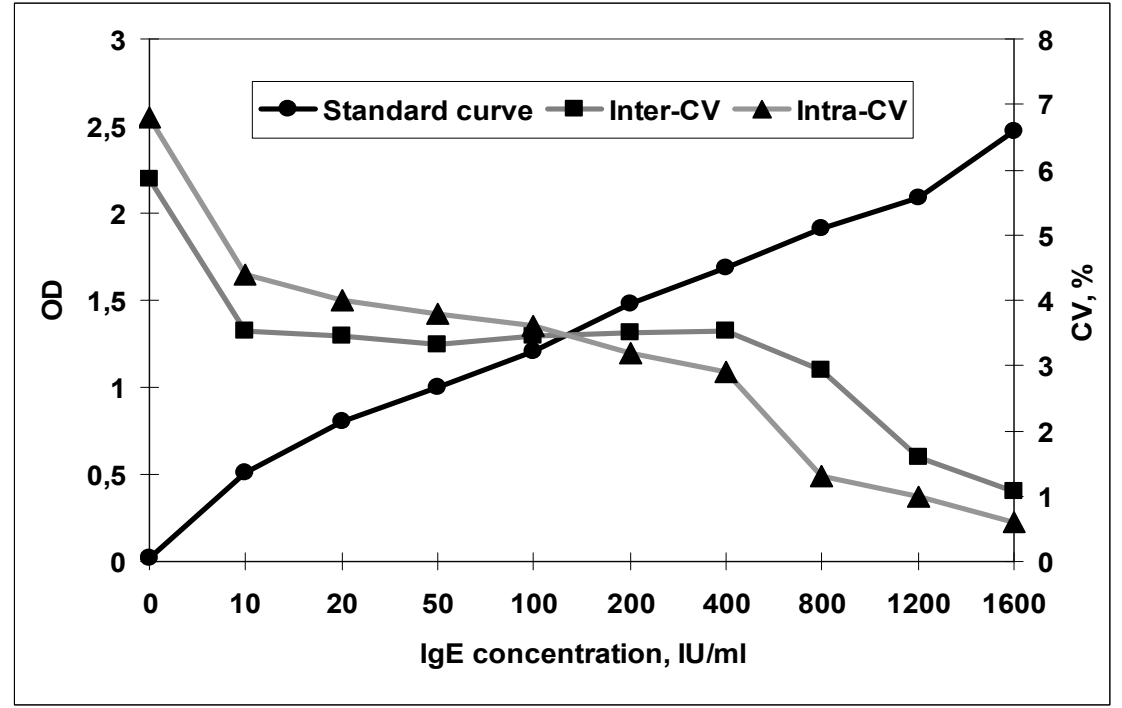

Figure 2. Standard curve of "sandwich" ELISA (-•-) and variability level of IgE standard concentrations determination in on procedure (Intra-CV; $-\mathbf{-}-)$ and between the procedures (Inter- $\mathrm{CV} ;-\mathbf{\Delta}-$ ).

On standards' level IgE test-kit demonstrated the accepted variability values basing on variation coefficient parameters during one procedure (intra-CV $=4.2 \pm 2.1 \%$ ) and between the procedures (inter-CV $=4.8 \pm 2.3 \%$ ). Values of intra-CV and inter-CV are stabilized in rather wide $\mathrm{IgE}$ concentration range $(20-1200 \mathrm{IU} / \mathrm{ml})$ and slightly increased in boundary concentrations of immunoglobulin (0-20 $\mathrm{IU} / \mathrm{ml})$, showing the biggest test resolution in IgE concentrations determination starting from $20 \mathrm{IU} / \mathrm{ml}$. IgE concentrations determination over $400 \mathrm{IU} / \mathrm{ml}$ is defined by the maximum stability (intra-CV $\leq 1.32 \%$, inter- $\mathrm{CV} \leq 2.90 \%$ ), additionally evidencing that upper limit of dynamic range in the elaborated ELISA isn't associated with MAbs binding sites saturation, but is caused by possibilities of detection photometric method.

It is known that cross reactivity of one or two MAbs (ELISA was elaborated on their basis) with structurally relative IgE proteins can be a reason of false-negative or false-positive results correspondingly. In order to detect cross reactivity immunoglobulins of other types (human $\mathrm{IgG}, \mathrm{IgA}, \mathrm{IgM}$ ) and albumin with concentration $1 \mu \mathrm{g} / \mathrm{ml}$ were added to ELISA reaction mixture with known concentration of $\operatorname{IgE}(50 \mathrm{IU} / \mathrm{ml})$. Their effect was interpreted as detection effectiveness (\%) of the known human $\operatorname{IgE}$ concentration (results difference of IgE concentration determination of samples with concentration 50 and $0 \mathrm{IU} / \mathrm{ml}$, expressed in percentage).

Not one of serum proteins test samples did not influence determination of human IgE test-concentration (table 4). Therefore the elaborated "sandwich" ELISA did not show any cross reactivity with other serum proteins.
Table 4. Cross reactivity of "sandwich" ELISA with human serum proteins.

\begin{tabular}{llll}
\hline $\begin{array}{llll}\text { Protein } \\
(\mathbf{1} \boldsymbol{\mu} \mathbf{g} / \mathbf{m l})\end{array}$ & Human IgE & & Detection, \% \\
\cline { 2 - 4 } (0 IU/ml & $\mathbf{5 0 ~ I U / m l}$ & \\
\hline Human IgG & 0 & 99.7 & 99.7 \\
Human IgA & 0 & 101.4 & 101.4 \\
Human IgM & 0 & 100.9 & 100.9 \\
Albumin & 0 & 100.7 & 100.7 \\
\hline
\end{tabular}

\section{Conclusions}

Based on complex analysis results of monoclonal antibodies to human IgE it was proved that antibodies of B-A1 and B-A3 epitopes are the most possible "sandwich" combination for creation of noncompetitive ELISA. Sorbtion-detection ability of different MAb pairs correlates with their affinity. The best antibodies for catching (usage in immunosorbent) are B epitope antibodies (163D12, 164H10), and for detections (usage in immunoenzymatic conjugate) are A1 MAb epitopes (165C12, 166A10, 167B4) and A3 (161A7, 164F5, 166B7). The most expressed sorbtion-detection abilities have two pairs of high affinity MAbs 164H10 - 165C12 and 164H10 166B7. Common usage of MAb immunoenzymatic conjugates, directed to different antigen determinants $165 \mathrm{C} 12$ (epitope A1) 166B7 (epitope A3), causes sensitivity increase when relatively low human $\operatorname{IgE}$ concentrations were analyzed $(<600 \mathrm{IU} / \mathrm{ml})$.

The elaborated test-kit for total IgE assay has shown 
the sensitivity which has double superiority to nephelometry or turbidimetry methods $(4.5 \mathrm{IU} / \mathrm{ml})$. The dynamic range of the elaborated ELISA has 3 levels (4.5-1600 $\mathrm{IU} / \mathrm{ml}$ ), when for the majority of commercial test-kits the dynamic range has 2 levels. Variability values (variation coefficient value during one procedure (intra-CV $=$ $4.2 \pm 2.1 \%$ ) and between procedures (inter-CV = $4.8 \pm 2.3 \%)$ ) are accepted for this method. None of the test serum proteins (human $\operatorname{IgG}, \operatorname{IgA}$, IgM, albumin) influences determination of test concentration $(50 \mathrm{IU} / \mathrm{ml})$ of human IgE.

\section{References}

[1] E. Harlow, D. Lane, Antibodies. A laboratory manual. N.Y.: Cold Spring Harbor, 1988. pp. 7-23.

[2] K. Ishizaka, T. Ishizaka, M. Hornbrook, "Physicochemical properties of human reaginic antibody. IV. Presence of a unique immunoglobulin as a carrier of reaginic activity", J. Immunol., vol. 97 (1), pp. 75-85, July 1966.

[3] D. R. Stanworth, J. H. Humphrey, H. Bennich et al., "Specific inhibition of the Prausnitz-Küstner reaction by an atypical human myeloma protein", Lancet, vol. 290 (7511), pp. 330-332, August 1967.

[4] A. J. Bonnin, F. Montealegre, A. Gewurz, "Association of cigarette smoking with elevated serum IgE levels in Hispanic Puerto Rican men", Ann. Allergy, vol. 67, pp. 609611, December 1991.

[5] A. Miadonna, C. Zanussi, "IgE synthesis in aging. Enhancement of IgE production in subjects with autoantibodies", Boll. Ist. Sieroter. Milan, vol. 58, pp. 75-80, March 1979.

[6] K. J. Erb, "Helminths, allergic disorders and IgEmediated immune responses: where do we stand?", Eur. J. Immunol., vol. 37 (5), pp. 1170-1173, May 2007.

[7] J. Duarte, P. Deshpande, V. Guiyedi et al., "Total and functional parasite specific IgE responses in Plasmodium falciparum-infected patients exhibiting different clinical status", Malar. J., vol. 6, pp. 1-13, January 2007.

[8] D. Isaacs, D. G. Altman, C. E. Tidmarsh et al., "Serum immunoglobulin concentrations in preschool children measured by laser nephelometry: reference ranges for $\mathrm{IgG}$, IgA, IgM", J. Clin. Pathol., vol. 36 (10), pp. 1193-1196, October 1983.

[9] J. W. Skoug, H. L. Pardue, "Effects of reaction variables on nephelometric and turbidimetric responses for the immunochemical reaction of immunoglobulin G", Clin. Chem., vol. 34 (2), pp. 300-308, February 1988.

[10] V. S. Chowdary, E. C. Vinaykumar, J. J. Rao et al., “A study on serum IgE and eosinophils in respiratory allergy patients", Indian J. Allergy Asthma Immunol., vol 17 (1), pp. 21-24, January 2003.

[11] B. Lanier, "Anti-IgE as a practical tool in asthma management: observations and warnings from clinical experience", Cur. Allergy Clin. Immunol., vol. 18 (3), pp. 104106, August 2005.

[12] N. Novak, T. Bieber, "Allergic and non-allergic forms of atopic disease", J. Allergy. Clin. Immunol., vol. 112, pp. 252-262, January 2003.

[13] A. V. Kulakov, S. V. Klimov, D. A. Yarilin et al., "The study of the natural affinity of the human serum antibodies to component of the bacterial cell wall - muramyl dipeptide glycoside with adjuvant activity", Immunol., vol. 1, pp. 21-24, January 1997. (in Russian).

[14] P. Tijssen, "Practice and theory of enzyme immunoassays", Lab. Techiques in Biochem. and Molecular Biology, vol. 15, pp. 558-562, 1985.

[15] O. Yu. Galkin, A. A. Savchenko, K. I. Nikitina et al., "Obtaining and study of the properties of new monoclonal antibodies to human IgE", Ukrainian Biochem. J., 2013. (in press). (in Ukrainian).

[16] V. P. Shirobokov, I. V. Nikolaenko, L.V. Kopanytsya et al., "The panel of monoclonal antibodies for inside type differentiation of polioviruses type II", vol. 59 (6), pp. 27-36, Microbiol. J., December 1997. (in Ukrainian). 